\title{
Novel pharmacological MC4R agonists can efficiently activate mutated MC4R from obese patient with impaired endogenous agonist response
}

\author{
Pierre Roubert, Béatrice Dubern ${ }^{1,2,3}$, Pascale Plas, Cécile Lubrano-Berthelier ${ }^{1,3}$, Rohia Alihi ${ }^{1,3,4}$, \\ Florence Auger, Daniel B Deoliveira ${ }^{5}$, Jesse Z Dong ${ }^{5}$, Arnaud Basdevant ${ }^{1,3,4}$, Christophe Thurieau \\ and Karine Clément ${ }^{1,3,4}$ \\ IPSEN Innovation, 5 Avenue du Canada, 91940 Les Ulis, France \\ ${ }^{1}$ Center of Research on Human Nutrition Ile de France, CRNH, Pitié-Salpêtrière Hospital, 47 Boulevard de I'hôpital, 75013 Paris, France \\ ${ }^{2}$ Department of Pediatric Nutrition and Gastroenterology, Assistance Publique-Hôpitaux de Paris (AP-HP), Armand-Trousseau Hospital, 26 Avenue du Docteur A \\ Netter, 75012 Paris, France \\ ${ }^{3}$ Inserm, U872 team7 Nutriomique, Cordelier Research Center, Pierre et Marie Curie-Paris-6 University, 15 rue de I'école de médecine, 75006 Paris, France \\ ${ }^{4}$ Department of Endocrinology and Nutrition, Assistance Publique-Hôpitaux de Paris (AP-HP), Pitié Salpêtrière Hospital, 47 Boulevard de I'hôpital, 75013 Paris, \\ France \\ ${ }^{5}$ Biomeasure Incorporated, IPSEN, 27 Maple Street, Milford, Massachusetts 01757, USA
}

(Correspondence should be addressed to B Dubern; Email: beatrice.dubern@trs.aphp.fr; or P Roubert; Email: pierre.roubert@ipsen.com)

\begin{abstract}
Human melanocortin 4 receptor (hMC4R) mutations with in vitro functional effects are responsible for $0 \cdot 5-2 \cdot 5 \%$ of severe obesity. Designing ligands that are able to counteract this in vitro-associated molecular defect is crucial to develop specific anti-obesity drugs in these genetically associated cases. We analyzed the in vitro effect of two novel melanocortin agonists, IRC-022493 and IRC-022511, on typical hMC4R mutations chosen based on the nature of their functional alterations, i.e. intracytoplasmic retention and/or reduced basal activity and/or reduced $\alpha-\mathrm{MSH}$ potency. We assessed the in vitro ability of IRC-022493 and IRC-022511 to bind and activate hMC4R mutants. These mutations were found earlier in 11 obese French patients (median age (range) was $17 \cdot 6$ years $(5 \cdot 7-48 \cdot 0)$ and body mass index $(\mathrm{BMI})-Z$-score $4 \cdot 2$ s.D. $(1 \cdot 5-5 \cdot 5)$. The MC4R agonists were responsible for a
\end{abstract}

significant activation of mutated hMC4R depending on the functional characteristics of the mutations. Both agonists were able to activate mutated hMC4R with decreased $\alpha-\mathrm{MSH}$ potency, associated with or without decreased basal activity, to the same extent than $\alpha-M S H$ in wild-type MC4R. This result suggests that those mutations would be the best targets for the MC4R agonists among MC4R mutation-bearing obese patients. No specific clinical phenotype was associated with the differential response to pharmacological agonists. We identified two novel melanocortin agonists that were able in vitro to efficiently activate mutated $\mathrm{hMC} 4 \mathrm{R}$ with impaired endogenous agonist functional response. These results stimulate interest in the development of these drugs for hMC4R mutations-associated obesity.

Journal of Endocrinology (2010) 207, 177-183

\section{Introduction}

Melanocortin 4 receptor (MC4R) mutations are responsible for the most common genetic cause of human obesity (Farooqi 2008). The discovery of human MC4R (hMC4R) mutations affecting the receptor function pointed out not only the predominant role of MC4R in body weight regulation (Mutch \& Clement 2006) but also reinforced the interest in the development of MC4R agonist to control obesity (Mackenzie 2006).

MC4R receptor encodes a G-protein-coupled receptor, which transduces signals by coupling to the heterotrimeric Gs protein and activating adenylate cyclase. Expressed in hypothalamic nuclei controlling food intake, MC4R integrates an agonist (anorexigenic) signal provided by the pro-opiomelanocortin product, $\alpha$-melanocyte stimulating hormone $(\boldsymbol{\alpha}-\mathrm{MSH})$, and an antagonist (orexigenic) signal provided by the agouti-related peptide. The role of MC4R in energy balance was first demonstrated in mice (Huszar et al. 1997); MC4R invalidated mice develop severe obesity while heterozygous animals are less obese. MC4R activation both by natural and pharmacological agonists decreased food intake in rodents and improved their metabolic conditions (Fan et al. 1997).

In humans, the frequency of hMC4R mutations with in vitro functional consequences is relatively high $(0 \cdot 5-6 \%)$ in obese adults and children of European and North America origins (Farooqi et al. 2000, 2003, Vaisse et al. 2000, 
Yeo et al. 2003, Hinney et al. 2006, Lubrano-Berthelier et al. 2006, Calton et al. 2009), while it is significantly $<1 \%$ in controls $(0 \cdot 1-0 \cdot 6 \%)$ (Hinney et al. 2006, Lubrano-Berthelier et al. 2006, Stutzmann et al. 2008). Individuals are mostly heterozygous carriers of mutated hMC4R with an autosomic dominant inheritance and variable penetrance and expressivity with age and generational influences (Stutzmann et al. 2008). While different classifications have been proposed (Tao \& Segaloff 2003, Biebermann et al. 2006, Lubrano-Berthelier et al. 2006, Tan et al. 2009), the functional consequences of hMC4R mutations can be schematically divided into the following categories: nonfunctional truncated receptor (i.e. due to missense or frameshift mutations), intracellular retention, altered basal activity, and altered $\boldsymbol{\alpha}$-MSH stimulation. Synthetic ligands, from classical NDP-MSH peptides to the multiple tetrapeptides and small molecule MC4R agonists, have been tested in vitro with distinct improvement of hMC4R functional activity depending on both agonist potency and nature of the mutation (Ujjainwalla \& Sebhat 2007, Xiang et al. 2007). Determining which of the hMC4R mutations might be pharmacologically rescued by newly developed MC4R agonists is a promising approach to identify potential patients who may benefit the most from such drug candidates. In this study, we describe the in vitro effects of two novel melanocortin agonists on a set of selected mutated hMC4R, representative of previously established mutation classes (Dubern et al. 2001, Lubrano-Berthelier et al. 2006).

\section{Materials and Methods}

\section{hMC4R mutations}

We studied the effect of IRC-022493 (Dong \& Moreau 2007) and IRC-022511 (Dong et al. 2008), two novel MC4R agonists, on 11 hMC4R mutations described earlier in obese adults and children (Dubern et al. 2001, Lubrano-Berthelier et al. 2006; Fig. 1B). The mutations were chosen among the various categories found in obese patients based on their known in vitro functional alterations such as intracytoplasmic retention (Pro299His and Ile102Ser) (class 1), reduced basal activity (Arg18Cys, Arg18His, Val50Met, and Gly231Ser) (class $2 \mathrm{~A}$ ), reduced $\boldsymbol{\alpha}$-MSH potency (Ser127Leu) (class $2 \mathrm{~B}$ ), or the association of both reduced basal activity and $\alpha-\mathrm{MSH}$ potency (Arg305Trp, Ser58Cys, Ile102Thr, and Gly252Ser) (class 2C). Subjects were obese adults and children (median age (range) $17 \cdot 6$ years $(5 \cdot 7-48 \cdot 0)$, and median body mass index (BMI)- $Z$-score (range) $4 \cdot 2$ s.D. $(1 \cdot 5-5 \cdot 5)$ ) participating in a previous genetic study performed at HôtelDieu and Trousseau hospitals, Assistance Publique Hôpitaux de Paris, France. Some MC4R mutations were detected in new patients (Ser127Leu, Ileu102Thr, and Gly252Ser; Fig. 1A (Dubern et al. 2001, Lubrano-Berthelier et al. 2006)). The subjects were phenotyped for a series of clinical and biological parameters related to obesity (anthropometric measures, blood pressure, carbohydrate, insulin, and lipid measurements). Informed consent was obtained from all subjects and the protocol was approved by the local ethics committee.

\section{hMC4R agonists}

IRC-022493 and IRC-022511 are peptide melanocortin analogs, which specifically bind hMC4R with inhibition constants $\left(K_{\mathrm{i}}\right)$ of $2 \cdot 1$ and $2 \cdot 4 \mathrm{nM}$ respectively, being 20 - and 17 -fold more potent than $\alpha-\mathrm{MSH}$ respectively. Activation of hMC4R by IRC-022493 and IRC-022511 stimulates intracellular cAMP production with $50 \%$ effective concentrations $\left(\mathrm{EC}_{50}\right)$ of 0.31 and $0.099 \mathrm{nM}$ respectively, being 15 - and 47 -fold more potent than $\alpha$-MSH respectively. By peripheral administration, IRC-022493 and IRC-022511 were shown earlier to reduce food intake and body weight gain in normal rats (Halem et al. 2006) and to improve obesity, hyperinsulinemia, and fatty liver disease in diet-induced obese mice (Kumar et al. 2009). $\alpha$-MSH was purchased from Bachem (Weil am Rhein, Germany).

\section{$h M C 4 R$ cloning and expression}

Wild-type and mutated $h M C 4 R$ genes from genomic DNA were cloned into a pcDNA5/FRT/V5-His-TOPO expression vector. After transformation and selection of Escherichia coli, the transformant plasmids were extracted, and selected using the restriction enzyme EcoRI and sequenced to confirm the presence of the mutation. For each gene, one of the established transformants was amplified and purified following the manufacturer's conditions (TA expression kit, Invitrogen). CHO flip-in cells were stably cotransfected with hMC4R and pOG44 recombinase using the Flip-In system (Invitrogen) and effectene transfection reagent (Qiagen). Transfected cells were selected with hygromycin.

\section{Binding to $h M C 4 R$}

Membranes were obtained by sonication of CHO flip-in cells stably expressing wild-type or mutated hMC4R in $50 \mathrm{mM}$ Tris- $\mathrm{HCl}, \mathrm{pH} 7 \cdot 4$, and centrifugation at $39000 \mathrm{~g}$ for $10 \mathrm{~min}$ at $4{ }^{\circ} \mathrm{C}$. The pellet was resuspended in the same buffer and centrifuged at $50000 \mathrm{~g}$ for $10 \mathrm{~min}$ at $4{ }^{\circ} \mathrm{C}$ and membranes in the resulting pellet were stored at $-80^{\circ} \mathrm{C}$. Competitive inhibition of $\left[{ }^{125} \mathrm{I}\right]\left(\mathrm{Tyr}^{2}\right)-\left(\mathrm{Nle}^{4}-\mathrm{D}-\mathrm{Phe}^{7}\right)-\alpha-\mathrm{MSH} \quad\left(\left[{ }^{125} \mathrm{I}\right]-\right.$ NDP- $\boldsymbol{\alpha}-\mathrm{MSH}$; PerkinElmer, Les Ulis, France) binding was run in polypropylene 96 -well plates. Cell membranes $(25 \mu \mathrm{g}$ protein/well) were incubated in $50 \mathrm{mM}$ Tris- $\mathrm{HCl}, \mathrm{pH} 7 \cdot 4$, containing $0 \cdot 2 \% \mathrm{BSA}, 5 \mathrm{mM} \mathrm{MgCl}, 1 \mathrm{mM} \mathrm{CaCl}_{2}$, and $0.1 \mathrm{mg} / \mathrm{ml}$ bacitracin, with $0.4 \mathrm{nM}\left[{ }^{125} \mathrm{I}\right]-\mathrm{NDP}-\alpha-\mathrm{MSH}$ and increasing concentrations of unlabeled $\alpha-\mathrm{MSH}$, IRC022493, or IRC-022511 for $2 \mathrm{~h}$ at $37^{\circ} \mathrm{C}$. The number of binding sites was determined by performing saturation experiments with increasing concentrations of [ $\left.{ }^{125} \mathrm{I}\right]-\mathrm{NDP}-$ $\alpha-\mathrm{MSH}$. Bound from free $\left[{ }^{125} \mathrm{I}\right]-\mathrm{NDP}-\alpha-\mathrm{MSH}$ was separated by filtration through GF/C glass fiber filter plates 


\begin{tabular}{|c|c|c|c|c|c|c|c|c|c|}
\hline Mutation & Age & Sex & BMI & BMI-Z-score & G T0 & Ins & TG & $\mathrm{TC}$ & $\begin{array}{c}\text { Classification } \\
\text { of mutation }\end{array}$ \\
\hline Ile102Ser* & $16 y$ & $\mathrm{M}$ & $34 \cdot 8$ & 4.1 S.D. & $4 \cdot 8$ & $11 \cdot 0$ & $0 \cdot 6$ & $4 \cdot 7$ & Class 1 \\
\hline $\operatorname{Arg} 18 \mathrm{Cys}^{\circ}$ & $42 y$ & $\mathrm{~F}$ & $52 \cdot 6$ & 3.4 S.D. & $5 \cdot 5^{\#}$ & $15 \cdot 4$ & $0 \cdot 7$ & 5.4 & \\
\hline $\operatorname{Arg} 18 \mathrm{His}^{\circ}$ & $33 y$ & $\mathrm{~F}$ & $40 \cdot 6$ & 3.0 S.D. & $6 \cdot 7$ & $13 \cdot 0$ & $1 \cdot 3$ & $4 \cdot 6$ & Class 2A \\
\hline Val50Met* & $6 y$ & M & $24 \cdot 2$ & 5.5 S.D. & $4 \cdot 8$ & $9 \cdot 6$ & $0 \cdot 6$ & $4 \cdot 4$ & \\
\hline${\text { Gly } 231 S e r^{\circ}}^{\circ}$ & $48 y$ & M & $41 \cdot 6$ & 3.7 S.D. & $6 \cdot 7^{\#}$ & $20 \cdot 3$ & $2 \cdot 3$ & $4 \cdot 8$ & \\
\hline Ser127Leu & $8 y$ & $\mathrm{~F}$ & $25 \cdot 5$ & 4.8 S.D. & $4 \cdot 3$ & $4 \cdot 7$ & $0 \cdot 7$ & $4 \cdot 8$ & Class 2B \\
\hline Ser58Cys* & $12 y$ & F & $33 \cdot 0$ & 4.2 S.D. & $5 \cdot 0$ & $46 \cdot 0$ & $0 \cdot 8$ & $3 \cdot 3$ & \\
\hline Ile102Thr & $29 y$ & M & $46 \cdot 0$ & 4.9 S.D. & $5 \cdot 5$ & $18 \cdot 0$ & ND & ND & \\
\hline Gly252Ser & $16 y$ & $\mathrm{~F}$ & $24 \cdot 2$ & 1.5 S.D. & $3 \cdot 9$ & $6 \cdot 3$ & $0 \cdot 8$ & 4.9 & Class 2C \\
\hline $\operatorname{Arg} 305 \operatorname{Trp}^{\circ}$ & $19 y$ & $\mathrm{~F}$ & $41 \cdot 6$ & 4.3 S.D. & $5 \cdot 0$ & ND & $1 \cdot 5$ & $4 \cdot 1$ & \\
\hline
\end{tabular}

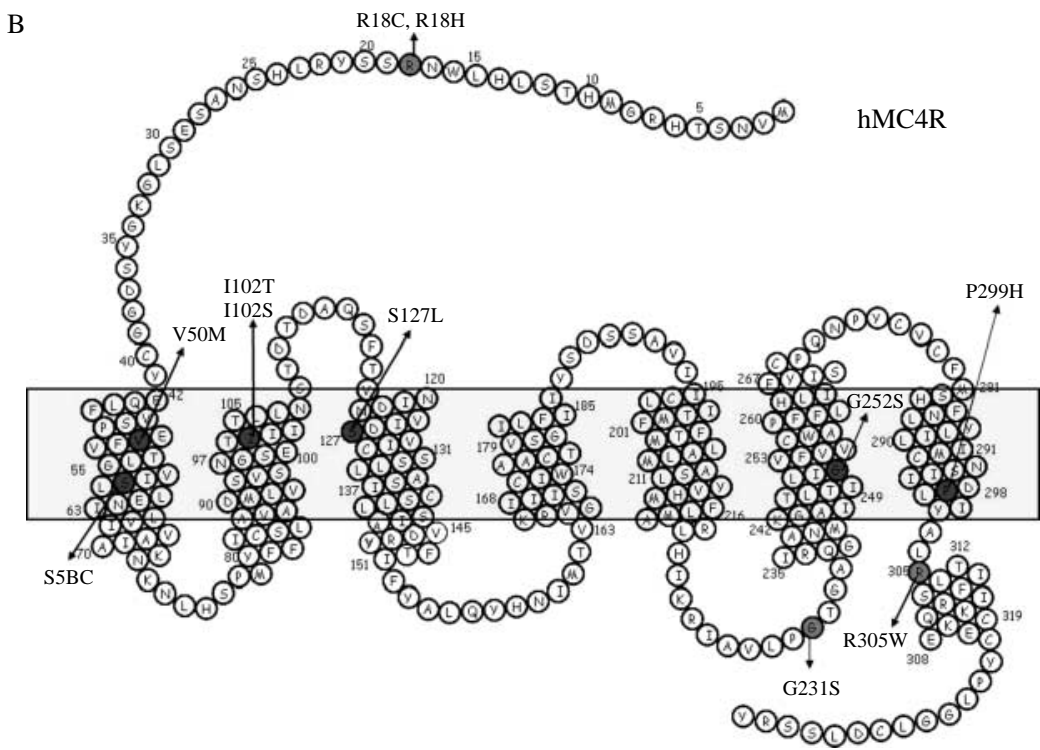

Figure 1 (A) Clinical characteristic of the individuals in each mutation category. $*$ and ${ }^{\circ}$ indicate mutation found in subjects previously described in Dubern et al. (2001) and Lubrano-Berthelier et al. (2006) respectively. BMI, body mass index $\left(\mathrm{kg} / \mathrm{m}^{2}\right) ; \mathrm{G} \mathrm{T0}$, fasting glucose $(\mathrm{mmol} / \mathrm{l})$; Ins, fasting insulin $(\mu \mathrm{U} / \mathrm{ml}) ; \mathrm{TG}$, triacylglycerol $(\mathrm{mmol} / \mathrm{l}) ; \mathrm{TC}$, total cholesterol $(\mathrm{mmol} / \mathrm{l})$; the other mutations have been found recently in these French subjects. ${ }^{\#}$ Stands for subjects with noninsulin-dependant diabetes. (B) Position of the 11 chosen mutations. The mutations studied are indicated in black circles.

(Unifilter; PerkinElmer) presoaked with $0 \cdot 1 \%(\mathrm{w} / \mathrm{v})$ polyethylenimine, using PerkinElmer Filtermate harvester. Filters were washed three times with $50 \mathrm{mM}$ Tris- $\mathrm{HCl}, \mathrm{pH}$ $7 \cdot 4$, at $0-4{ }^{\circ} \mathrm{C}$ and assayed for radioactivity using PerkinElmer Topcount scintillation counter. Binding data were analyzed by computer-assisted nonlinear regression analysis (XL fit; IDBS, Guildford, UK).

\section{Determination of intracellular $c A M P$}

Intracellular cAMP levels were determined by an electrochemiluminescence (ECL) assay (Meso Scale Discovery (MSD), Gaithersburg, MD, USA). CHO flip-in cells stably expressing wild-type or mutated hMC4R were suspended in RMPI 1640 containing $0.5 \mathrm{mM}$ isobutylmethylxanthine and $0 \cdot 2 \%$ BSA. They were dispensed (30000 cells/well) in 384-well Multi-Array plates (MSD) containing integrated carbon electrodes and coated with anti-cAMP antibody. Increasing concentrations of $\alpha$-MSH, IR C-022493, or IRC022511 were added and the cells were incubated for $6 \mathrm{~h}$ at $37^{\circ} \mathrm{C}$. Then, a lysis buffer (HEPES-buffered saline solution with $\mathrm{MgCl}_{2}$ and Triton X-100, $\mathrm{pH} 7 \cdot 3$ ) containing $0 \cdot 2 \%$ BSA and $2.5 \mathrm{nM}$ TAG ruthenium-labeled cAMP (MSD) was added and the cells were incubated for $90 \mathrm{~min}$ at room temperature. At the end of the incubation period, a Tris-buffered solution containing an ECL co-reactant and Triton X-100, $\mathrm{pH} 7 \cdot 8$, was added and cAMP levels in cell lysates were immediately determined by ECL detection with a Sector Imager 6000 reader (MSD). Data were analyzed by computer-assisted nonlinear regression analysis (XL fit; IDBS). 
Table 1 Binding of $\alpha$-melanocyte stimulating hormone $(\alpha-M S H)$, IRC-022493 and IRC-022511 to mutated human melanocortin 4 receptor (hMC4R). The inhibition constant $\left(K_{\mathrm{i}}\right)$ and number of binding sites $\left(B_{\max }\right)$ values represent the mean \pm S.E.M. of three independent determinations

\begin{tabular}{|c|c|c|c|c|c|}
\hline \multirow[t]{2}{*}{ Mutation } & \multicolumn{3}{|l|}{$\boldsymbol{K}_{\mathbf{i}}(\mathrm{nM})$} & \multirow{2}{*}{$\frac{\boldsymbol{B}_{\mathbf{m a x}}(\mathrm{fmol} / \mathrm{mg} \text { protein })}{\left[{ }^{125} \mathrm{I}\right]-\mathrm{NDP}-\alpha-\mathrm{MSH}}$} & \multirow[t]{2}{*}{$\begin{array}{c}\text { Classification } \\
\text { of mutation }\end{array}$} \\
\hline & $\alpha-M S H$ & IRC-022493 & IRC-022511 & & \\
\hline WT & $26 \pm 7 \cdot 0$ & $0 \cdot 71 \pm 0 \cdot 27$ & $0 \cdot 71 \pm 0 \cdot 16$ & $98 \pm 5 \cdot 7$ & Class 1 \\
\hline Ile102Ser & $260 \pm 89$ & $4 \cdot 7 \pm 2 \cdot 2$ & $0 \cdot 84 \pm 0 \cdot 25$ & $23 \pm 3 \cdot 1$ & \\
\hline Pro299His & - & - & - & - & \\
\hline Arg18Cys & $16 \pm 5 \cdot 7$ & $0 \cdot 37 \pm 0 \cdot 034$ & $0 \cdot 65 \pm 0 \cdot 060$ & $40 \pm 5 \cdot 4$ & Class 2A \\
\hline Arg18His & $16 \pm 1 \cdot 2$ & $0.49 \pm 0.095$ & $0.42 \pm 0.045$ & $61 \pm 10$ & \\
\hline Val50Met & $22 \pm 2 \cdot 6$ & $0.79 \pm 0.17$ & $0.63 \pm 0.11$ & $68 \pm 14$ & \\
\hline Gly231Ser & $28 \pm 7 \cdot 3$ & $0 \cdot 58 \pm 0 \cdot 17$ & $0 \cdot 68 \pm 0 \cdot 15$ & $104 \pm 27$ & \\
\hline Ser127Leu & $160 \pm 40$ & $3 \cdot 3 \pm 0 \cdot 13$ & $2 \cdot 6 \pm 0 \cdot 34$ & $88 \pm 18$ & Class 2B \\
\hline Ser58Cys & $53 \pm 12$ & $1 \cdot 7 \pm 4 \cdot 3$ & $0.97 \pm 0.13$ & $27 \pm 5 \cdot 0$ & Class 2C \\
\hline Ile102Thr & $210 \pm 94$ & $2 \cdot 2 \pm 0 \cdot 21$ & $0 \cdot 85 \pm 0 \cdot 12$ & $50 \pm 2 \cdot 5$ & \\
\hline Gly252Ser & $160 \pm 66$ & $2 \cdot 3 \pm 0 \cdot 30$ & $1 \cdot 6 \pm 0 \cdot 29$ & $50 \pm 3 \cdot 5$ & \\
\hline Arg305Trp & $130 \pm 33$ & $2 \cdot 5 \pm 0 \cdot 57$ & $2 \cdot 2 \pm 0 \cdot 61$ & $190 \pm 16$ & \\
\hline
\end{tabular}

\section{Results}

We first evaluated our in vitro system by confirming the functional consequences of each hMC4R mutation in their ability to bind (Table 1) and be activated (Table 2) by their natural agonist $\alpha-\mathrm{MSH}$. Figure 2A illustrates $\alpha$-MSH-stimulated cAMP production for one hMC4R mutation in each functional category. When compared with our previously described in vitro system (Vaisse et al. 2000, Lubrano-Berthelier et al. 2006), the $\mathrm{EC}_{50}$ of $\alpha$-MSH was generally higher but the ratio between wild-type and each mutated receptor was conserved (data not shown). When $\alpha$-MSH potency was decreased (class $2 \mathrm{~B}$ and $2 \mathrm{C}$ mutations and Ile102Ser), the alteration was more pronounced in the receptor activation efficacy than binding affinity with the exception of Arg305Trp that only showed a reduced binding affinity (Tables 1 and 2). For most mutations, the number of $\left[{ }^{125} \mathrm{I}\right]-\mathrm{NDP}-\alpha-\mathrm{MSH}$ binding sites $\left(B_{\max }\right)$ was between 23 and $106 \%$ of wild-type hMC4R (Table 1). $B_{\max }$ was correlated to the maximal stimulation observed with $\alpha-$ MSH $\left(E_{\max }\right) . E_{\max }$ values were included between 38 and $111 \%$ of wild-type hMC4R (Table 2). Two exceptions were noticed: Pro299His (class 1) whose complete absence of binding and stimulation by $\alpha-\mathrm{MSH}$ was observed and, intriguingly, Arg305Trp that elicited $B_{\max }$ and $E_{\max }$ of 192 and $8 \%$ of wild-type hMC4R respectively. Taken together, these results being similar to previous ones (Vaisse et al. 2000, Lubrano-Berthelier et al. 2003, 2006) confidently allowed us to use this in vitro system to test the pharmaceutical agonists.

Table 2 Intracellular cAMP production by $\alpha$-melanocyte stimulating hormone ( $\alpha$-MSH), IRC-022493 and IRC-022511 on mutated human melanocortin 4 receptor (hMC4R). The $50 \%$ effective concentration $\left(E_{50}\right)$ and maximal stimulation $\left(E_{\max }\right)$ values represent the mean \pm s.E.M. of 2-3 independent determinations

\begin{tabular}{|c|c|c|c|c|c|c|c|}
\hline \multirow[t]{2}{*}{ Mutation } & \multicolumn{3}{|l|}{$\mathrm{EC}_{50}(\mathrm{nM})$} & \multicolumn{3}{|c|}{$\boldsymbol{E}_{\max }\left(\mathrm{pmol} / 10^{6}\right.$ cells $)$} & \multirow[t]{2}{*}{$\begin{array}{l}\text { Classification } \\
\text { of mutation }\end{array}$} \\
\hline & $\alpha-M S H$ & IRC-022493 & IRC-022511 & $\alpha-M S H$ & IRC-022493 & IRC-022511 & \\
\hline WT & $30 \pm 7 \cdot 5$ & $1 \cdot 5 \pm 0 \cdot 38$ & $0 \cdot 70 \pm 0 \cdot 24$ & $1900 \pm 130$ & $2100 \pm 140$ & $2000 \pm 150$ & Class 1 \\
\hline Ile102Ser & $12000 \pm 820$ & $100 \pm 11$ & $21 \pm 3 \cdot 0$ & $1100 \pm 51$ & $1400 \pm 57$ & $1300 \pm 59$ & \\
\hline Pro299His & - & - & - & - & - & - & \\
\hline Arg18Cys & $34 \pm 6 \cdot 2$ & $1 \cdot 9 \pm 0 \cdot 55$ & $0.92 \pm 0.33$ & $720 \pm 140$ & $770 \pm 170$ & $780 \pm 160$ & Class 2A \\
\hline Arg18His & $16 \pm 2 \cdot 0$ & $0.93 \pm 0 \cdot 18$ & $0.43 \pm 0.081$ & $1100 \pm 180$ & $1300 \pm 220$ & $1300 \pm 210$ & \\
\hline Val50Met & $37 \pm 12$ & $2 \cdot 0 \pm 0 \cdot 80$ & $0.96 \pm 0.46$ & $1400 \pm 58$ & $1500 \pm 58$ & $1400 \pm 54$ & \\
\hline Gly231Ser & $33 \pm 7 \cdot 8$ & $1 \cdot 9 \pm 0.52$ & $0 \cdot 79 \pm 0 \cdot 12$ & $2100 \pm 38$ & $2300 \pm 38$ & $2200 \pm 110$ & \\
\hline Ser127Leu & $640 \pm 190$ & $17 \pm 6 \cdot 0$ & $5 \cdot 2 \pm 1 \cdot 3$ & $1500 \pm 66$ & $1600 \pm 54$ & $1500 \pm 31$ & Class 2B \\
\hline Ser58Cys & $670 \pm 90$ & $46 \pm 8 \cdot 0$ & $19 \pm 4 \cdot 0$ & $800 \pm 140$ & $950 \pm 150$ & $960 \pm 150$ & Class 2C \\
\hline Ile102Thr & $5800 \pm 850$ & $150 \pm 57$ & $38 \pm 15$ & $1000 \pm 351$ & $1100 \pm 362$ & $1000 \pm 290$ & \\
\hline Gly252Ser & $210 \pm 45$ & $13 \pm 2 \cdot 0$ & $8 \pm 2 \cdot 0$ & $1400 \pm 71$ & $1500 \pm 67$ & $1500 \pm 8 \cdot 0$ & \\
\hline Arg305Trp & $15 \pm 2 \cdot 3$ & $0 \cdot 87 \pm 0 \cdot 15$ & $0 \cdot 61 \pm 0 \cdot 070$ & $160 \pm 29$ & $170 \pm 32$ & $150 \pm 32$ & \\
\hline
\end{tabular}



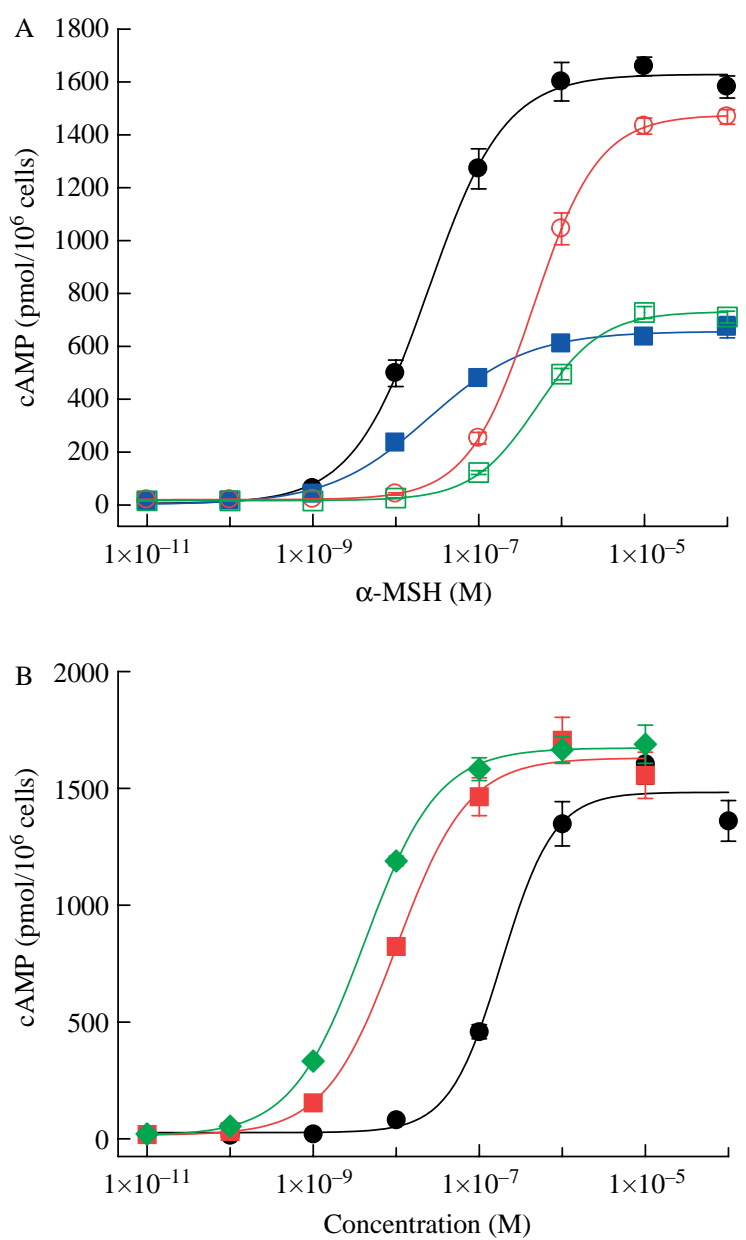

Figure 2 (A) cAMP production by $\alpha-M S H$ in wild-type (black closed circle) and three hMC4R mutations with distinct functional effect: Arg18Cys (blue closed square, class 2A), Ser127Leu (red open circle, class 2B), and Ser58Cys (green open square, class 2C). Data represent the results of a typical experiment that was replicated three times. (B) Stimulation of cAMP production by IRC-022493 (red squares) and IRC-022511 (green diamonds) in comparison with a-MSH (black circles) in Gly252Ser, a class 2C hMC4R mutation. Data represent the results of a typical experiment that was replicated three times.

We evaluated the ability of the two ligands (IRC-022493 and IRC-022511) to bind and activate the hMC4R mutants. Whatever the mutation, the maximal stimulation of cAMP production $\left(E_{\max }\right)$ obtained with IRC-022493 or IRC022511 was similar to the level reached by $\alpha$-MSH (Table 2 ). However, IRC-022493 showed a 28- to 95-fold higher affinity for MC4R (Table 1) and a 15- to 120-fold increased potency in stimulating cAMP (Table 2) than $\alpha-\mathrm{MSH}$. Comparable results were obtained with IRC-022511. IRC-022511 was 25- to 310-fold and 25- to 571-fold more potent than $\alpha-\mathrm{MSH}$ in binding (Table 1) and activating (Table 2) MC4R respectively.

Both agonists revealed increased potencies as compared to $\alpha$-MSH on either wild-type or the mutated hMC4R, but the relevance in terms of beneficial activation of MC4R depended on the functional consequences of each mutation. In the case of primary major altered binding and cAMP stimulation by $\alpha-\mathrm{MSH}$, i.e. for hMC4R mutations in class $2 \mathrm{~B}$ (decreased $\alpha-\mathrm{MSH}$ potency) and class $2 \mathrm{C}$ (decreased basal activity and $\alpha-\mathrm{MSH}$ potency), both agonists were able to reach the stimulation level of the natural ligand in wild-type hMC4R, especially for the mutations Ser127Leu, Ser58Cys, Ile102Thr, and Gly252Ser (Table 2). Figure 2B shows the comparative stimulation of cAMP production induced by $\alpha-\mathrm{MSH}$, IRC-022493, and IRC-022511 in the Gly252Ser hMC4R mutation. For hMC4R mutations associated with a decreased basal activity (class $2 \mathrm{~A}$ ), we could not predict the response even if an increased MC4R stimulation capacity was observed. In the case of a major reduced membrane expression (class 1), the agonists may lead to an enhanced hMC4R activation when part of the receptors remains reachable to the ligands (Ile102Ser). Otherwise, no benefit can be provided by the agonists (Pro299His).

We examined whether a specific clinical phenotype would be associated with the presence of hMC4R mutations that might be preferentially targeted by the agonists. No significant difference for each clinical and metabolic phenotype (age, sex, BMI-Z-score, blood pressure, and metabolic parameters) was found between the subjects separated according to the in vitro response of hMC4R mutations to the agonists (data not shown).

\section{Discussion}

This work shows that novel melanocortin agonists, IRC022493 and IRC-022511, are able to offset in vitro the impaired endogenous agonist response of class $2 \mathrm{~B}$ and $2 \mathrm{C}$ mutated hMC4R to the level of $\alpha-\mathrm{MSH}$ in wild-type receptor. In a recent study (Xiang et al. 2007), distinct relative potencies versus $\boldsymbol{\alpha}$-MSH were observed for synthetic agonists depending on the mutated receptor as compared with wild-type hMC4R. In agreement with that work, differences in IRC-022493 and IRC-022511 potency depended on the mutation type, although in this study, the potency ratio of IRC-022493 or IRC-022511 versus $\boldsymbol{\alpha}$-MSH was unchanged in mutated hMC4R as compared to wild-type hMC4R. In case of primary intracellular retention (class 1), the pharmacological agonists can improve hMC4R stimulation only if the receptor remains accessible to the ligands (Ile102Ser). When the hMC4R mutation induces a reduced basal activity with normal responsiveness to $\alpha-\mathrm{MSH}$ (class 2A), the physiological response to the agonists cannot be anticipated but undesired overstimulation of the receptor might not be excluded. The beneficial effects of IRC-022493 and IRC-022511 appear to be of marked interest for hMC4R mutations with decreased $\alpha$-MSH response (class $2 \mathrm{~B}$ and $2 \mathrm{C}$ ). Mutations that are rescued by the pharmacological agonists (Ser58Cys, Ile102Thr, Ile102Ser, Ser127Leu, and Gly252Ser) are located in key domains involved in interactions between 
hMC4R and the ligands. Except for Ser127Leu, they are positioned closer to the cytoplasmic side of the lipid bilayer and are likely to be involved in ligand-induced conformational changes important for G-protein-induced signal transduction events (Xiang et al. 2007). Ser127Leu is located in the third transmembrane domain and was described to be an important residue for interacting with the endogenous melanocortin conserved His-Phe-Arg-Trp residues. Ser127 residue might be important for receptor local hydrogen bonding interactions that might shift the hMC4R from the inactive to the active conformation state on ligand binding (Xiang et al. 2007).

Our results reinforce the importance of the functional characterization of hMC4R mutations to categorize the different classes of MC4R mutations, and thus identify mutation-bearing patients who might benefit the most from MC4R agonist therapy. Mutations with decreased endogenous $\alpha$-MSH response appear to be the best candidate responders for IRC-022493 and IRC-022511. Moreover, no specific clinical phenotype permits the selection of patients, who could benefit from such pharmacological treatment. Most mutations are found at the heterozygous state and little is known about MC4R dimerization in vivo. In addition, previous studies showed no dominant negative effect for intracellular retained receptors (Ho \& MacKenzie 1999, Yeo et al. 2003) and only one hMC4R mutation was described to result in a dominant-negative effect (Biebermann et al. 2003). Whether the pharmacological agonists could stimulate the mutated hMC4R without affecting the wildtype hMC4R protein remains to be explored.

No significant differences in clinical and metabolic phenotype were found between the subjects separated according to the in vitro response of hMC4R mutations to the two novel agonists. However, the spread variability of plasma triacylglycerol (TG) observed in obese patients may be in accordance with studies showing the direct role of the central melanocortin system on peripheral lipid metabolism (Nogueiras et al. 2007). Indeed, blockade of MC4R directly increases lipid uptake and TG synthesis in the periphery most likely through effects on autonomic outflow, inducing a decrease in plasma TG. Furthermore, it was demonstrated very recently that IRC-022493 improves hepatic steatosis reducing liver lipid and TG content in diet-induced obese mice (Kumar et al. 2009). Those data suggest that MC4R agonists may have a protective effect on lipid metabolism and especially TG synthesis.

In both preclinical and clinical studies, the role of the melanocortin system in penile erection, in modulation of the cardiovascular system, in inflammatory responses, and in pain processing has been described suggesting the risk of side effects when using melanocortin agonists (Adan et al. 2006, Shadiack et al. 2007). However, a very recent clinical study showed the influence of a pharmacological agonist on blood pressure and underlined the interest of MC4R agonist administration to MC4R mutation carriers since they had lower blood pressure than MC4R wild-type carriers (Greenfield et al. 2009).

In conclusion, we have shown that in vitro functional classification of hMC4R mutations using pharmacological agonists is an attractive approach for identifying the most promising responders among the obese population of MC4R mutation-bearing patients. Using this strategy, we demonstrated that mutated hMC4R with impaired endogenous agonist functional response can be activated by IRC-022493 and IRC-022511, and might represent a valuable therapeutic target for these novel melanocortin agonists. This observation suggests an interest in the development of specific drugs in hMC4R mutationsassociated obesity.

\section{Declaration of interest}

P R, P P, F A, D B D, J Z D, and C T are employed by IPSEN. B D, C L-B, $\mathrm{R} \mathrm{A}, \mathrm{A} \mathrm{B}$, and $\mathrm{K} \mathrm{C}$ declare that there is no conflict of interest that could be perceived as prejudicing the impartiality of the research reported.

\section{Funding}

This work was supported in part by the APHP (PHRC 1996), the GIP-ANR (National Agency of Research), the Benjamin Délessert Institute, the Guigoz Company, and the IPSEN group.

\section{Author contribution statement}

P R, B D, and C L-B designed the study. K C, A B, and B D recruited and performed the phenotyping of the patients. P R, P P, R A, F A, D B D, J Z D, and $\mathrm{C} \mathrm{T}$ developed the agonists and experiments. P R, B D, P P, and K C analyzed the data and wrote the paper.

\section{Acknowledgements}

We thank the patients and their families for their participation in the genetic study. We also thank R Delille and J G Marin for help in receptor cloning and expression, and E Ferrandis for his helpful suggestions.

\section{References}

Adan RA, Tiesjema B, Hillebrand JJ, la Fleur SE, Kas MJ \& de Krom M 2006 The MC4 receptor and control of appetite. British Journal of Pharmacology 149 815-827. (doi:10.1038/sj.bjp.0706929)

Biebermann H, Krude H, Elsner A, Chubanov V, Gudermann T \& Gruters A 2003 Autosomal-dominant mode of inheritance of a melanocortin-4 receptor mutation in a patient with severe early-onset obesity is due to a dominant-negative effect caused by receptor dimerization. Diabetes $\mathbf{5 2}$ 2984-2988. (doi:10.2337/diabetes.52.12.2984)

Biebermann H, Castaneda TR, van Landeghem F, von Deimling A, Escher F, Brabant G, Hebebrand J, Hinney A, Tschop MH, Gruters A et al. 2006 A role for beta-melanocyte-stimulating hormone in human body-weight regulation. Cell Metabolism 3 141-146. (doi:10.1016/j.cmet.2006.01.007)

Calton MA, Ersoy BA, Zhang S, Kane JP, Malloy MJ, Pullinger CR,

Bromberg Y, Pennacchio LA, Dent R, McPherson R et al. 2009

Association of functionally significant melanocortin-4 but not

www.endocrinology-journals.org 
melanocortin-3 receptor mutations with severe adult obesity in a large North-American case-control study. Human Molecular Genetics 18 1140-1147. (doi:10.1093/hmg/ddn431)

Dong ZX \& Moreau JP 2007 Melanocortin receptor ligands. International patent WO 2007/008704.

Dong ZX, DeOliveira \& Comstock JM 2008 Melanocortin receptor ligands modified with hydantoin. International patent WO 2008/147556.

Dubern B, Clement K, Pelloux V, Froguel P, Girardet J, Guy-Grand B \& Tounian P 2001 Mutational analysis of melanocortin-4 receptor, agouti-related protein, and alpha-melanocyte-stimulating hormone genes in severely obese children. Journal of Pediatrics 139 204-209. (doi:10.1067/ mpd.2001.116284)

Fan W, Boston BA, Kesterson RA, Hruby VJ \& Cone RD 1997 Role of melanocortinergic neurons in feeding and the agouti obesity syndrome. Nature 385 165-168. (doi:10.1038/385165a0)

Farooqi IS 2008 Monogenic human obesity. Frontiers of Hormone Research 36 1-11. (doi:10.1159/000115333)

Farooqi IS, Yeo GS, Keogh JM, Aminian S, Jebb SA, Butler G, Cheetham T \& O'Rahilly S 2000 Dominant and recessive inheritance of morbid obesity associated with melanocortin 4 receptor deficiency. Journal of Clinical Investigation 106 271-279. (doi:10.1172/JCI9397)

Farooqi IS, Keogh JM, Yeo GS, Lank EJ, Cheetham T \& O’Rahilly S 2003 Clinical spectrum of obesity and mutations in the melanocortin 4 receptor gene. New England Journal of Medicine 348 1085-1095. (doi:10.1056/ NEJMoa022050)

Greenfield JR, Miller JW, Keogh JM, Henning E, Satterwhite JH, Cameron GS, Astruc B, Mayer JP, Brage S, See TC et al. 2009 Modulation of blood pressure by central melanocortinergic pathways. New England Journal of Medicine 360 44-52. (doi:10.1056/ NEJMoa0803085)

Halem HA, Roubert P, Taylor JE, Plas P, De Oliveira DB, Comstock JM, Dong JZ \& Culler MD 2006 Novel, selective, peptide MC4 receptor agonists that decrease food intake and body weight in vivo. Proceedings of the 88th Annual Meeting of the Endocrine Society P3-75 655.

Hinney A, Bettecken T, Tarnow P, Brumm H, Reichwald K, Lichtner P, Scherag A, Nguyen TT, Schlumberger P, Rief W et al. 2006 Prevalence, spectrum, and functional characterization of melanocortin-4 receptor gene mutations in a representative population-based sample and obese adults from Germany. Journal of Clinical Endocrinology and Metabolism 91 1761-1769. (doi:10.1210/jc.2005-2056)

Ho G \& MacKenzie RG 1999 Functional characterization of mutations in melanocortin-4 receptor associated with human obesity. Journal of Biological Chemistry 274 35816-35822. (doi:10.1074/jbc.274.50.35816)

Huszar D, Lynch CA, Fairchild-Huntress V, Dunmore JH, Fang Q, Berkemeier LR, Gu W, Kesterson RA, Boston BA, Cone RD et al. 1997 Targeted disruption of the melanocortin-4 receptor results in obesity in mice. Cell 88 131-141. (doi:10.1016/S0092-8674(00)81865-6)

Kumar KG, Sutton GM, Dong JZ, Roubert P, Plas P, Halem HA, Culler MD, Yang H, Dixit VD \& Butler AA 2009 Analysis of the therapeutic functions of novel melanocortin receptor agonists in MC3R-and MC4R-deficient C57BL/6J mice. Peptides 30 1892-1900. (doi:10.1016/j.peptides.2009.07.012)

Lubrano-Berthelier C, Durand E, Dubern B, Shapiro A, Dazin P, Weill J, Ferron C, Froguel P \& Vaisse C 2003 Intracellular retention is a common characteristic of childhood obesity-associated MC4R mutations. Human Molecular Genetics 12 145-153. (doi:10.1093/hmg/ddg016)

Lubrano-Berthelier C, Dubern B, Lacorte JM, Picard F, Shapiro A, Zhang S, Bertrais S, Hercberg S, Basdevant A, Clement K et al. 2006 Melanocortin 4 receptor mutations in a large cohort of severely obese adults: prevalence, functional classification, genotype-phenotype relationship, and lack of association with binge eating. Journal of Clinical Endocrinology and Metabolism 91 1811-1818. (doi:10.1210/jc.2005-1411)

Mackenzie RG 2006 Obesity-associated mutations in the human melanocortin-4 receptor gene. Peptides 27 395-403. (doi:10.1016/j.peptides.2005. 03.064)

Mutch DM \& Clement K 2006 Unraveling the genetics of human obesity. PLoS Genetics 2 e188. (doi:10.1371/journal.pgen.0020188)

Nogueiras R, Wiedmer P, Perez-Tilve D, Veyrat-Durebex C, Keogh JM, Sutton GM, Pfluger PT, Castaneda TR, Neschen S, Hofmann SM et al. 2007 The central melanocortin system directly controls peripheral lipid metabolism. Journal of Clinical Investigation 117 3475-3488. (doi:10.1172/ JCI31743)

Shadiack AM, Sharma SD, Earle DC, Spana C \& Hallam TJ 2007 Melanocortins in the treatment of male and female sexual dysfunction. Current Topics in Medicinal Chemistry 7 1137-1144. (doi:10.2174/ 156802607780906681)

Stutzmann F, Tan K, Vatin V, Dina C, Jouret B, Tichet J, Balkau B, Potoczna N, Horber F, O'Rahilly S et al. 2008 Prevalence of melanocortin-4 receptor deficiency in Europeans and their agedependent penetrance in multigenerational pedigrees. Diabetes $\mathbf{5 7}$ 2511-2518. (doi:10.2337/db08-0153)

Tan K, Pogozheva ID, Yeo GS, Hadaschik D, Keogh JM, Haskell-Luevano C, O'Rahilly S, Mosberg HI \& Farooqi IS 2009 Functional characterization and structural modeling of obesity-associated mutations in the melanocortin 4 receptor. Endocrinology 150 114-125. (doi:10.1210/en. 2008-0721)

Tao YX \& Segaloff DL 2003 Functional characterization of melanocortin-4 receptor mutations associated with childhood obesity. Endocrinology 144 4544-4551. (doi:10.1210/en.2003-0524)

Ujjainwalla F \& Sebhat IK 2007 Small molecule ligands of the human melanocortin-4 receptor. Current Topics in Medicinal Chemistry 7 1068-1084. (doi:10.2174/156802607780906609)

Vaisse C, Clement K, Durand E, Hercberg S, Guy-Grand B \& Froguel P 2000 Melanocortin-4 receptor mutations are a frequent and heterogeneous cause of morbid obesity. Journal of Clinical Investigation 106 253-262. (doi:10. 1172/JCI9238)

Xiang Z, Pogozheva ID, Sorenson NB, Wilczynski AM, Holder JR, Litherland SA, Millard WJ, Mosberg HI \& Haskell-Luevano C 2007 Peptide and small molecules rescue the functional activity and agonist potency of dysfunctional human melanocortin-4 receptor polymorphisms. Biochemistry 46 8273-8287. (doi:10.1021/bi7007382)

Yeo GS, Lank EJ, Farooqi IS, Keogh J, Challis BG \& O’Rahilly S 2003 Mutations in the human melanocortin-4 receptor gene associated with severe familial obesity disrupts receptor function through multiple molecular mechanisms. Human Molecular Genetics 12 561-574. (doi:10. 1093/hmg/ddg057)

Received in final form 29 July 2010

Accepted 9 August 2010

Made available online as an Accepted Preprint 9 August 2010 